\title{
Prekonsepsiyonel Dönemdeki Kadınların Sağlık Davranışları Değişim Aşamaları (Transteoretik Model): Randomize Kontrollü Çalışma
}

\section{Women's Health Behaviors Stages of Change (Transtheoretical Model) in Preconception Period: A Randomized Control Study}

iD Yasemin Erkal Aksoy', iD Melek Gülsün Özentürk².

${ }^{1}$ Selçuk Üniversitesi, Sağlık Bilimleri Fakültesi, Ebelik Bölümü, Konya, Türkiye

${ }^{2}$ Ege Üniversitesi, Sağlık Bilimleri Fakültesi, Ebelik Bölümü, İzmir, Türkiye

$\ddot{O} z$

Amaç: Prekonsepsiyonel bakım, gebelik planlayan ya da gebelik düşünmeyen bir kadının sağlığını, sağlık davranışlarını ve bilgilerini optimize etmek olarak tanımlanabilir. Bu çalışmanın amacı; hiç gebelik yaşamamış, gebelik düşünen kadınlara verilen eğitimin kadınlardaki sağlık davranışları değişim aşamalarına (transteoretik model) etkisinin incelenmesidir.

Gereç ve Yöntem: Araştırma, randomize kontrollü eğitim müdahale çalışmasıdır. Örneklem büyüklüğü G*Power 3.1 .7 programı ile her grupta en az 88 kadın olarak hesaplanmıştır. Çalışma 180 kadın ile sonlandırılmıştır. Merkeze gelen kadınlar örneklem kriterleri açısından değerlendirilmiş ve randomize örnekleme yöntemi ile iki gruba ayrılmıştır. İlk görüşmede tüm kadınlara: Tanıtıcı Bilgi Formu, Prekonsepsiyonel Risk Değerlendirme Formu, Değişim Aşamalarını Değerlendirme Formu, Sağlıklı Yaşam Biçimi Davranışları Ölçeği-II, Genel Öz-Yeterlilik Ölçeği doldurtulmuştur. Girişim grubundaki kadınlara gebeliğe hazırlık eğitimi ve Prekonsepsiyonel Bakım Rehberi adlı bir rehber kitap verilmiştir. Kontrol grubundaki kadınlara eğitim verilmemiștir.

Bulgular: Girişim grubunda yer alan kadınların; folik asit kullanma, düzenli fiziksel aktivite uygulama, yeterli ve dengeli beslenme açısından değişim aşamaları ön-son test sonuçlarına göre aralarında bulunan farkın istatistiksel olarak da anlamlı olduğu saptanmıştır.

Sonuç: Prekonsepsiyonel dönemde verilen gebeliğe hazırlık eğitiminin, folik asit kullanımı, düzenli fiziksel aktivite, yeterli ve dengeli beslenme değişim aşamaları açısından etkili olduğu, ölçek puan ortalamalarında anlamlı artış sağladığı belirlenmiştir.

Anahtar Kelimeler: Prekonsepsiyonel dönem, transteoretik model, eğitim, gebeliğe hazırlık, ebelik

Abstract

Objective: Preconceptional care can be defined as optimizing the health, health behaviors and information of a woman who plans a pregnancy. The study's aim was to investigate the effect given education women who have never had any pregnancy, considering pregnancy to stages of change of health behaviors in women.

Materials and Methods: The study is a randomized controlled education intervention trial. The sample size was calculated to be at least 88 women in each group with G* Power 3.1 .7 program. The study was terminated with 180 women. The women who came to the center were evaluated in terms of sample criteria and randomized sampling was divided into two groups. In the first interview, all the women were given: Introductory Information Form, Preconceptional Risk Assessment Form, Evaluation Form of Change Stages, Healthy Lifestyle Behavior Scale-II and General Self-Efficacy Scale. Women who intervention group was training to preparation for pregnancy and was given a guide book called on Preconception Care Guide. Women in the control group were not trained.

Results: The women in intervention group between pre-post test results statistically was found to be increased significant difference that based on the effect health behaviors on the stages of change given education about use of folic acid, practice of regular physical activity, adequate and balanced nutrition.

Conclusions: Pregnancy preparation training given in the preconception period had a positive effect on the use of folic acid, regular physical activity, and change in health behaviors towards adequate and balanced nutrition, general self-efficacy level and healthy lifestyle behaviors.

Key Words: Preconception period, transtheoretical model, education, pregnancy preparation, midwifery

18-19 Nisan 2019 tarihinde 3. Uluslararası Kadın ve Çocuk Sağlığı ve Eğitimi Kongresi Trabzon/Türkiye sözel bildiri olarak sunulmuştur.

Yazışma Adresi: Yasemin Erkal Aksoy, Selçuk Üniversitesi, Sağlık Bilimleri Fakültesi, Ebelik Bölümü, Konya, Türkiye

E-Posta: ebeyaseminerkal@hotmail.com

Alınma tarihi: 28.08.2020 / Kabul tarihi: 24.09.2020 / Yayımlanma tarihi: 15.12.2021

Prekonsepsiyonel Dönemdeki Kadınların Sağlık Davranışları Değişim

Genel Tip Derg 2021;31(4)330-338

Aşamaları - Erkal Aksoy ve Özentürk. 
sağlık davranışları değişim aşamalarına (transteoretik model) etkisinin incelenmesidir.

Dünya genelinde doğum öncesi ve sonrası bakım oranlarının artmasına rağmen doğum sonuçlarında istendik düzeyde başarı elde edilememesi doğum öncesi bakımın geç bir dönem olduğu düşüncesini ortaya çıkarmıştır. $\mathrm{Bu}$ durum kadınların gebelik öncesi yaşamındaki risklerini hedef alarak bütüncül bir yaklaşım çerçevesinde prekonsepsiyonel bakım bilincinin oluşmasına neden olmuştur $(1,2)$. Prekonsepsiyonel bakım, gebelik planlayan ya da gebelik düşünmeyen bir kadının sağlığını, sağlık davranışlarını ve bilgilerini optimize etmek olarak tanımlanabilir (3-5).

Prekonsepsiyonel sağlık göstergeleri; sigara, alkol kullanımı, kronik hastalık, mental bozukluklar, egzersiz yapmama, yetersiz beslenme, gebelik sonuçlarını olumsuz etkileyebilecek sosyal ve duygusal destek gibi değiştirilebilir risk faktörlerinden oluşur (6-8). Kadınların gebelik sonucunu etkileyebilecek risk faktörleri ile birlikte gebeliğe başlamaları, gebe ve fetüsün sağlığını olumsuz yönde etkilemektedir. Aynı zamanda kadınların davranışları, alışkanlıkları da gebelik sürecini olumlu ya da olumsuz etkileyebilir $(3,9)$. Uluslararas1 rehberlerde ve örgütlerin raporlarında prekonsepsiyonel bakımın bileşenleri; risk taraması, gebelik öncesi sağlığın geliştirilmesi ve eğitim (aşılama ve danışmanlık), belirlenen risklere yönelik girişimler olarak ifade edilmiştir (10-12).

Üreme çağındaki tüm kadınların gebelik sonuçlarını iyileştirmek için sağlık sorunları, uygun tıbbi bakım ve sağlıklı davranış geliştirmeye yönelik danışmanlık verilmelidir. Kadınlar ile karşılaşılan her firsatta sağlık profesyonelleri, "Gebelik düşünüyor musunuz?" veya “Gebelik planınız ne zaman?" gibi sorular ile prekonsepsiyonel bakım girişimlerinde bulunmalıdır (13-15). Gebelik yaşama ihtimali olan kadınlarda rutin yapılan fizik muayene, obstetrik ve jinekolojik öykülerinin alınmasının yanı sıra prekonsepsiyonel bakım içerisinde yer alan konularda ele alınmalıdır $(4,10,16,17)$. Ek olarak sağlıklı yaşam biçimi davranışlarının kazandırılması da kadının gebelik sırasında uyumunu kolaylaştıracaktır. Egzersiz, beslenme gibi bazı konularda sağlıklı alışkanlıkların kazanılması güçtür. Ancak gebelik planı, kadının davranış değiş̧imi konusunda motivasyonunu artırır.

Sağlık eğitimi, öz-yeterlilik gibi unsurlar kadının egzersiz, beslenme gibi konularda olumlu yönde değişim göstermesinde etkili olabilir $(18,19)$. Sağlık eğitimi, bireyin ve toplumun sağlığını iyileştirmek, bilgilerini arttırmak veya tutumlarını etkilemek üzere tasarlanmış öğrenme deneyimlerinin bileşimidir. Sağlık eğitiminin esas amacı, sağlık davranışında pozitif, bilgilendirilmiş değişikliklerdir $(20,21)$. Sağlık davranışı sağlık eğitiminin temel kaygısı olup her tanımında yer alır ve eğitim ile yapılan müdahale çalışmalarının çoğunda bağımlı değişkendir (20,22). Davranış Değişim Aşamaları Modeli (Transteoretik Model-TTM), davranış değişikliğinin çeşitli aşamalardan geçtiği varsayımına dayanmakta ve temelde bireyin değişim yapma hazırlığına odaklanmaktadır. TTM, diğer teorilerdeki temel yapıları birleştiren bütünleyici bir davranış değişikliği modelidir. Model, insanların sorunlu davranışı nasıl değiştirdiklerini veya nasıl olumlu davranış kazandıklarını açıklar $(21,23)$. Model düşünme öncesi, düşünme, hazırlık, hareket, devam ettirme aşamalarından oluşur $(20,24)$. Kadınlar için gebelik öncesi dönem gebelik için hazırlık yapılabilecek, bilgiye açık oldukları bir dönemdir. Gebeliğe hazırlık eğitimi ile kadınların sağlık davranışlarında değişim olacağı gerekçesiyle çalışma planlanmıştır. Bu çalışmanın amacı; hiç gebelik yaşamamış, gebelik düşünen kadınlara verilen eğitimin kadınlardaki

\section{Gereç ve Yöntem}

\section{Araştırma Türü}

Araştırma, randomize kontrollü eğitim müdahale çalışmasıdır.

\section{Araştırma Sorusu}

Hiç gebelik yaşamamış, gebelik düşünen kadınlara verilen gebeliğe hazırlık eğitimi, kadınlardaki sağlık davranışları değişim aşamalarını nasıl etkiler?

\section{Evren ve Örneklem}

Araştırma evrenini Türkiye'nin Konya ili Selçuklu İlçesinde bir aile sağlığ 1 merkezinde (ASM) bakım alan, hiç gebelik yaşamamış kadınlar oluşturmuştur. Türkiye'de ASM'ler birinci basamak sağlık hizmetlerinin sunulduğu birimlerdir. ASM'inde bireylerin bilgilerinin gizliliği nedeni ile evren sayısı elde edilememiştir. Araştırmanın örneklemine bu ASM'inde bakım alan hiç gebelik yaşamamış, ancak gebelik düşünen ve araştırmaya katılmayı kabul eden kadınlar alınmıştır. Örneklem büyüklüğü $\mathrm{G}^{*}$ Power 3.1 .7 programı ile $\% 5$ hata, \%80 güç, 0.3 etki büyüklügü (orta düzey etki) alındığında her grupta en az 88 kadın olarak hesaplanmıştır. Çalışma sürecinde kadınların çalışmadan ayrılmayı isteme, gebe kalma gibi dışlanma kriterleri düşünülerek \%15 oranında yedek alınmış ve toplam 204 kadına ulaşılmıştır. Araştırmanın başlangıcında Clinical trials kaydı yapılmış, kayıt numarası (NCT03893084) alınmıştır.

\section{Katılımcilar}

Araştırmaya katılmayı kabul edip yazılı onam veren, 18 yaş üstü, okuryazar olan, psikiyatrik/psikolojik tanıya dayalı bir rahatsızlığı olmayan, evli, hiç gebelik yaşamamış ve gebelik düşünen kadınlar alınmıştır. Araştırma sırasında ayrılmak isteyen ve gebelik yaşayan kadınlar çalışma dışında bırakılmıştır. Araştırmanın bağımlı değişkeni; kadınların sağlık davranışlarındaki değişimi, bağımsız değişkenleri; kadınların sosyo-demografik özellikleri, prekonsepsiyonel risk faktörleri ve gebeliğe hazırlık eğitimi olarak belirlenmiştir.

\section{Veri Toplama Yöntemi}

Araştırmanın veri toplama aşamasında 218 kadın örnekleme alınma kriterleri açısından değerlendirilmiş olup kritelere uymayan ve katılmayı reddeden 14 kadın çalışma dışında bırakılmıştır. Kadınlar randomize örnekleme yapılarak eşit iki gruba ayrılmıştır. Randomize örneklemenin yapılabilmesi için örneklem sayısı belirtilerek bilgisayar ortamında internet sitelerindeki programlar aracılığ ile rasgele sayllar tablosu otomatik olarak elde edilmiştir $(25,26)$. Girişim ve kontrol gruplarının belirlenmesinde yazı tura yöntemi kullanılmıştır (27). Girişim grubundan 11 kadın kontrol grubundan 13 kadın, ayrılmak istemeleri veya gebelik yaşamaları nedeniyle çalışmadan çıkarılmış olup, toplam 180 (girişim=91, kontrol=89) kadın ile çalışma sonlandırılmıştır. Şekil 1'de araştırmanın tasarımı (CONSORT şeması) yer almaktadır. Çalışmada tek körleme yöntemi kullanılmıştır. Çalışmaya katılan kadınlara hangi grupta yer aldığı bilgisi verilmemiştir. Araştırmacı gruplara ayırma, müdahalede

Prekonsepsiyonel Dönemdeki Kadınların Sağlık Davranışları

Değişim Aşamaları - Erkal Aksoy ve Özentürk. 
bulunma, veri toplama görevlerinde yer aldığı için körleme yapılmamıştır.

Birinci görüşme sırasında ön-test uygulaması yapılmış, Tanıtıcı Bilgi Formu, Prekonsepsiyonel Risk Değerlendirme Formu, Değişim Aşamalarını Değerlendirme Formu, Sağlıklı Yaşam Biçimi Davranışları Ölçeği-II, Genel Öz-Yeterlilik Ölçeği girişim ve kontrol grubunda bulunan tüm kadınlara doldurtulmuştur. Araştırma verileri soru-cevap şeklinde yüz yüze anket tekniği kullanılarak toplanmıştır.

\section{Girișim Grubu}

Kadınlara rutin hizmete ek olarak folik asit kullanımı, fiziksel aktivite, beslenme, madde bağımlılı̆̆ danışmanlık konularını içeren Prekonsepsiyonel Bakım Rehberi kullanılarak gebeliğe hazırlık eğitimi verilmiştir. Gebeliğe hazırlık eğitimi barkovizyonla yansıtılarak verilmiş olup ortalama 30-45 dakika kadar sürmüştür. Eğitim her kadına birebir verilmiş soru cevap şeklinde geri bildirim alınmıştır. Eğitim sonrası kadınlara Prekonsepsiyonel Bakım Rehberi kitapçı̆̆1 verilmiştir. Eğitimden dört hafta sonra kadınlara telefon edilerek eğitim ile ilgili hatırlatma izlemi yapılmıştır. Eğitimden sekiz hafta sonra kadınlara Değişim Aşamalarını Değerlendirme Formu, Sağlıkı Yaşam Biçimi Davranışları Ölçeği-II, Genel Öz-Yeterlilik Ölçeği son-test uygulaması yapılmıştır.

\section{Kontrol Grubu}

Kontrol grubundaki kadınlara eğitim verilmemiş, fiziksel muayene, 15-49 yaş kadın izlemi, kanser taraması gibi rutin uygulamalar yapılmıştır. Kontrol gruplarında yer alan kadınlara ilk görüşmeden sekiz hafta sonra Değişim Aşamalarını Değerlendirme Formu, Sağlıklı Yaşam Biçimi Davranışları Ölçeği-II, Genel Öz-Yeterlilik Ölçeği uygulanmıştır. Kontrol grubunda yer alan kadınlara, son-test uygulamasından sonra Prekonsepsiyonel Bakım Rehberi verilmiştir.

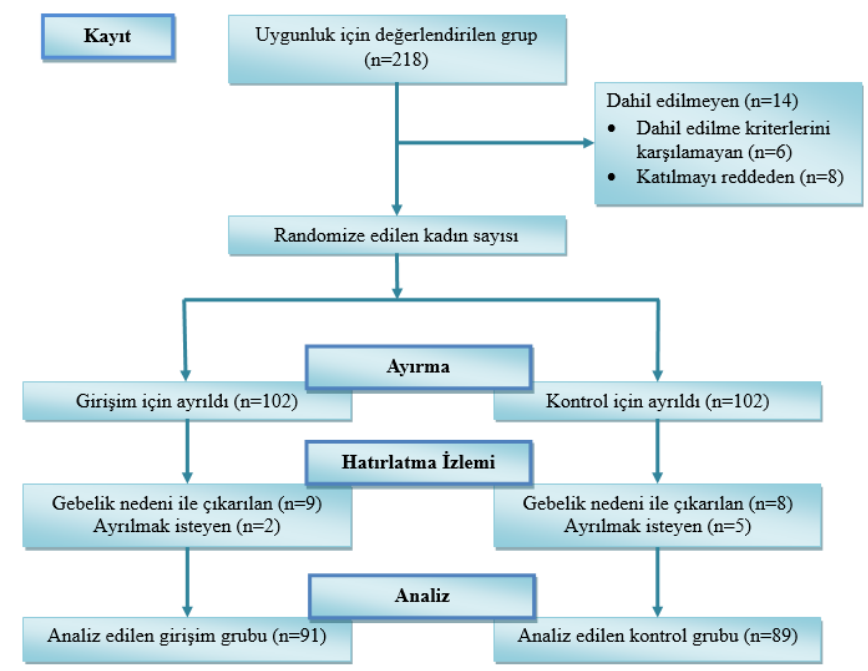

Şekil 1. Araştırmanın Tasarımı (CONSORT şeması)

\section{Kullanılan Gereçler}

\section{Tanıtıcı Bilgi Formu}

Araştırmacı tarafından hazırlanmış kadınların sosyodemografik özellikleri ve mevcut sağlık durumu hakkında sorular içermektedir.

\section{Prekonsepsiyonel Risk Değerlendirme Formu}

Gebelik oluşumunu ve sürecini etkileyebilecek, gebelik öncesi dönemde kadınlardaki riskleri belirlemek amacı ile araştırmacı tarafindan literatür taraması yapılarak oluşturulmuştur.

\section{Değişim Aşamalarını Değerlendirme Formu}

Araştırmacı tarafından, prekonsepsiyonel bakım kapsamında yer alan konulara yönelik davranış değişim aşamalarını değerlendirmek için oluşturulmuştur. Çalışmamızda folik asit, fiziksel aktivite, yeterli ve dengeli beslenme ve sigara kullanımı değişim aşamaları TTM adaptasyonu yapılarak soru formu oluşturulmuştur (Şekil 2). Sorulara verilen yanıtlar ile bireyin hangi davranış değişim aşamasında olduğu belirlenebilmektedir. Hareket ve sürdürme aşamasında olan bireyin ayrıntılı olarak değerlendirilebilmesi için her konuya özgü açık uçlu sorular sorulmuştur.

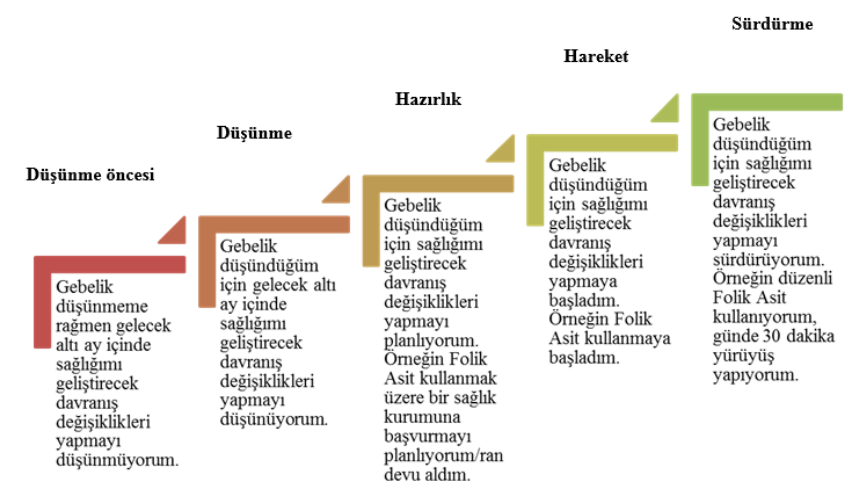

Şekil 2. Transteoretik Modele Göre Değişim Aşamaları ve Prekonsepsiyonel Bakıma Yönelik Adaptasyonu

\section{Sağlıklı Yaşam Biçimi Davranışları Ölçeği-II (SYBDÖ-II)}

Walker ve arkadaşları 1987 yılında bireyin sağlıklı yaşam biçimi ile ilişkili olarak sağlığı geliştiren davranışları değerlendiren ölçek geliştirmişlerdir (28). Türkçe geçerlik ve güvenirlik çalışması Bahar ve arkadaşları (2008) tarafından yapılmıștır (29). Toplam 52 maddeden oluşan ölçeğin tüm maddeleri olumludur. Ölçek dört seçenekli olup hiçbir zaman (1), bazen (2), sık sık (3), düzenli olarak (4) şeklinde puanlanmaktadır. Ölçeğin tamamı için en düşük puan 52, en yüksek puan 208 'dir. Ölçeğin toplam puanı sağlıklı yaşam biçimi davranışları puanını belirlemektedir. Ölçekte Sağlık Sorumluluğu, Fiziksel Aktivite, Beslenme, Manevi Gelişim, Kişilerarası İlişkiler, Stres Yönetimi olmak üzere altı alt boyut bulunmaktadır $(28,29)$.

\section{Genel Öz-Yeterlilik Ölçeği (GÖYÖ)}

Ölçek algılanan öz-yeterlik hakkında genel bir değerlendirme yapmak amac1 ile Ralf Schwarzer ve Mattihias Jerusalem (1995) tarafindan geliştirilmiştir (30). Ölçeğin Türkçe geçerlik güvenirlik çalışması Aypay (2010) tarafından yapılmıştır (31). On iki yaş ve üzeri bireylere uygulanan ölçek 10 maddeden oluşmaktadır. Öz-yeterlilik ölçeğinden, her biri 1'den 4'e kadar değişebilen puanlar alınmaktadır. Ölçekten elde edilen toplam en düşük puan 10, en yüksek puan 40'dır. Öz-yeterlilik ölçeğinden alınan yüksek puan, öz-yeterlilik düzeyinin yüksek olduğunu gösterir. 


\section{Prekonsepsiyonel Bakım Rehberi}

Araştırmacı tarafından, literatür bilgilerden yararlanılarak geliştirilmiş, farklı aşamadaki kadınların farklı ihtiyaçları olacağı dikkate alınarak hazırlanmıştır $(12-14,16)$. Temel alınan beş değişim aşaması kapsamında bireylere ayrı ayrı stratejiler sunulmuştur. Bireyin değişim aşaması Değişim Aşamaları Değerlendirme Formu ile belirlendikten sonra, saptanan aşamaya uygun olarak hazırlanmış bölümden değişime başlanabilmesine yönelik adımlar sunulmuştur. Rehber kitap, girişim grubunda yer alan kadınlara eğitim sonrası, kontrol grubunda yer alan kadınlara son-test uygulandıktan sonra verilmiştir.

\section{İstatistiksel Analiz}

Araştırma verilerinin analizi bilgisayarda IBM Statistical Package For Social Science (SPSS) 20.0 paket programında gerçekleştirilmiştir. Verilerin analizinde: Ölçüm değişkenleri ortalama $\pm 1 \quad \mathrm{~S}$ ile sınıflanmış veri ise sayı-yüzde tabloları ile sunulmuştur. Girişim ve kontrol gruplarının başlangıçta sayım değişkenleri ki-kare testleri ile çözümlenmiştir. Girişim ve kontrol gruplarının kendi içindeki değişimlerinin değerlendirilmesinde ölçüm değişkenleri için bağımlı grupta $\mathrm{t}$ testi (parametrik koşullar sağlanamadığı durumda Wilcoxon işaretli sıra testi), sayım değişkenlerinin değerlendirilmesinde ise, eğer grup ikili ise (örneğin folik asit kullanımı) McNemar ki-kare, üç ya da daha fazla kategoriden oluşuyorsa (örneğin değişimin aşamaları) Bowker testi kullanılmıştır. Girişim ve kontrol gruplarında ön ve son testte GÖYÖ ve SYBDÖ-II arasındaki birliktelik Pearson korelasyonu ile değerlendirilmiştir. Girişim ve kontrol gruplarında yer alan kadınlara eğitim öncesi ve eğitim sonrası uygulanan ölçeklerin puanlarını değerlendirmek için Bağımlı Gruplarda t Testi (Parametrik Olmayan Koşullarda Wilcoxon İşaretli Sıra Testi) kullanılmıştır. Veriler istatistiksel olarak $\mathrm{p}<0.05$ düzeyinde anlamlı kabul edilmiştir.

\section{Bulgular}

Kontrol grubunda 89, girişim grubunda 91 kadın olmak üzere toplam 180 kadın araştırma kapsamına alınmıştır. Kadınların yaş ortalaması girişim grubunda 26.21 \pm 3.68 ( $\mathrm{Min}=18, \mathrm{Max}=38)$, kontrol grubunda 26.96 \pm 3.66 (Min=20, Max=41) olarak belirlenmiştir. Kadınların yarısından fazlasının girişim grubunda 18-25 yaş arasında, kontrol grubunda ise 26-35 yaş arasında olduğu görülmektedir. Kadınların BKİ ortalaması sırasıyla girişim grubunda $22.53 \pm 3.42$ (Min=17.21, Max=35.43), kontrol grubunda 22.28 \pm 3.31 'dir (Min=17.58, $\mathrm{Max}=34.93$ ). BKİ sınıflamasına göre girişim ve kontrol grubu dengeli dağılmaktadır. Girişim grubunda üç, kontrol grubunda iki kadının obez olduğu görülmektedir. Girişim grubundaki kadınların \%67.0'si, kontrol grubundaki kadınların \%66.3'ü yükseköğretim mezunudur. Girişim (\%81.3) ve kontrol (\%77.5) grubundaki kadınların dörtte üçünden fazlası aylık gelir düzeyinin orta olduğunu ifade etmiştir. Girişim ve kontrol gruplarında yer alan kadınların, tanımlayıcı özellikleri açısından aralarında bulunan farkın istatistiksel olarak anlamlı olmadığg saptanmışıtır ( $>>0.05$ ) (Tablo 1).

Girişim ve kontrol grubundaki kadınların yarıdan fazlasının pasif içiciliğe maruz kaldıkları, reçetesiz/danışmadan ilaç (ağrı kesici, öksürük şurubu, vs.) kullanmakta oldukları, çiğ et yeme/çiğ ete temas durumu olduğu belirlenmiştir. Girişim grubunda yer alan kadınların \%58.2'si, kontrol grubunda yer alan kadınların \%68.5'inin daha önce gebelikten korunmak için herhangi bir yöntem kullandıkları belirlenmiş olup her iki grubunda sırasıly kondom/prezervatif, geri çekme, hap/oral kontraseptif/hormon iğneleri kullanmış olduğu görülmektedir. Kadınların tüm prekonsepsiyonel risk durumları açısından aralarında bulunan farkın istatistiksel olarak anlamlı olmadığı saptanmıştır ( $>0.05)$ (Tablo 2).

Girişim grubundaki kadınların gebelik ile ilişkili sağlıklı yaşam davranış özelliklerine ilişkin ön-son test sonuçlarına göre; folik asit hakkında bilgi, folik asit açısından zengin besinleri bilme, öğün sırası ve sonrası su içme, düzenli olarak günde 400 mikrogram folik asit kullanma ve düzenli fiziksel aktivite hakkında bilgi ile ilgili değişkenler arasında istatistiksel olarak anlamlı fark saptanmıştır $(\mathrm{p}<0.05)$. Diğer değişkenler arasında ön-son test sonuçlarına göre sayısal artışlar olmakla birlikte aralarında bulunan farkın istatistiksel olarak anlamlı olmadığı saptanmıştır ( $\mathrm{p}>0.05)$. Kontrol grubunda yer alan kadınların ise gebelik ile ilişkili sağlıklı yaşam davranış özelliklerine ait ön-son test sonuçlarına göre aralarında bulunan farkın istatistiksel olarak anlamlı olmadığı saptanmıştır ( $>0.05$ ) (Tablo 3).

Tablo 1. Kadınların Tanımlayıcı Özelliklerine Göre Dağılımı

\begin{tabular}{|c|c|c|c|}
\hline \multirow[b]{2}{*}{ Değişkenler } & \multicolumn{3}{|c|}{ Gruplar } \\
\hline & Girişim n=91 (\%) & $\begin{array}{c}\text { Kontrol } n=89 \\
(\%)\end{array}$ & p değeri \\
\hline \multicolumn{4}{|c|}{ BKİ grupları } \\
\hline Zayıf $<18,50$ & $8(8.8)$ & $9(10.1)$ & \multirow{4}{*}{$0.966^{*}$} \\
\hline Normal 18,50 - 24,99 & $66(72.5)$ & $64(71.9)$ & \\
\hline Fazla kilolu 25,00 - 29,99 & $14(15.4)$ & $14(15.7)$ & \\
\hline Obez $\geq 30,00$ & $3(3.3)$ & $2(2.3)$ & \\
\hline \multicolumn{4}{|c|}{ Öğrenim durumu } \\
\hline Okuryazar/ilkokul & $3(3.3)$ & $4(4.5)$ & \multirow{3}{*}{$0.917^{*}$} \\
\hline Ortaokul/lise & $27(29.7)$ & $26(29.2)$ & \\
\hline Üniversite ve üstü & $61(67.0)$ & $59(66.3)$ & \\
\hline \multicolumn{4}{|c|}{ Çalışma durumu } \\
\hline Çalışıyor & $42(46.2)$ & $52(58.4)$ & \multirow{2}{*}{$0.099^{*}$} \\
\hline Çalışmıyor & $49(53.8)$ & $37(41.6)$ & \\
\hline \multicolumn{4}{|c|}{ Aile tipi } \\
\hline Çekirdek aile & $84(92.3)$ & $82(92.1)$ & \multirow{2}{*}{$1.000^{* *}$} \\
\hline Geniş aile & $7(7.7)$ & $7(7.9)$ & \\
\hline \multicolumn{4}{|c|}{ Sosyal güvence durumu } \\
\hline Var & $85(93.4)$ & $86(96.6)$ & \multirow{2}{*}{$0.497 * * *$} \\
\hline Yok & $6(6.6)$ & $3(3.4)$ & \\
\hline \multicolumn{4}{|c|}{ Ailenin aylık gelir düzeyi } \\
\hline Gelir giderden az (düsüuk) & $2(2.2)$ & $5(5.6)$ & \multirow{3}{*}{$0.487^{*}$} \\
\hline Gelir gidere denk (orta) & $74(81.3)$ & $69(77.5)$ & \\
\hline $\begin{array}{c}\text { Gelir giderden çok } \\
\text { (yüksek) }\end{array}$ & $15(16.5)$ & $15(16.9)$ & \\
\hline
\end{tabular}

Tablo 2. Kadınların Prekonsepsiyonel Risk Durumlarına Göre

Prekonsepsiyonel Dönemdeki Kadınların Sağlık Davranışları Değişim Aşamaları - Erkal Aksoy ve Özentürk. 
Dağılımı

\begin{tabular}{|c|c|c|c|}
\hline & \multicolumn{3}{|c|}{ Gruplar } \\
\hline Değişkenler & Girişim n=91 (\%) & Kontrol n=89 (\%) & $\underset{\text { değeri }}{\mathbf{p}}$ \\
\hline \multicolumn{4}{|c|}{ Pasif içiciliğe maruz kalma } \\
\hline Evet & $51(56.0)$ & $45(50.6)$ & \multirow{2}{*}{$0.461^{*}$} \\
\hline Hayır & $40(44.0)$ & $44(49.4)$ & \\
\hline \multicolumn{4}{|c|}{ Sürekli kullanılan ilaç } \\
\hline Var & $15(16.5)$ & $10(11.2)$ & \multirow{2}{*}{$0.422 * *$} \\
\hline Yok & $76(83.5)$ & $79(88.8)$ & \\
\hline \multicolumn{4}{|c|}{ Reçetesiz/danışmadan ilaç (ağrı kesici, öksürük şurubu, vs.) Kullanma } \\
\hline Evet & $54(59.3)$ & $45(50.6)$ & \multirow{2}{*}{$0.237^{*}$} \\
\hline Hayır & $37(40.7)$ & $44(49.4)$ & \\
\hline \multicolumn{4}{|c|}{ Vitamin, zayıflama çayı, bitkisel ürün, ilaç dışı takviye kullanma } \\
\hline Evet & $28(30.8)$ & $18(20.2)$ & \multirow{2}{*}{$0.147 * *$} \\
\hline Hayır & $63(69.2)$ & $71(79.8)$ & \\
\hline \multicolumn{4}{|c|}{ Çiğ et yeme/çiğ ete temas durumu } \\
\hline Evet & $51(56.0)$ & $52(58.4)$ & \multirow{2}{*}{$0.747^{*}$} \\
\hline Hayır & $40(44.0)$ & $37(41.6)$ & \\
\hline \multicolumn{4}{|c|}{ Doktor tarafindan tanı konmuş anemi } \\
\hline Evet & $26(28.6)$ & $26(29.2)$ & \multirow{2}{*}{$0.924 *$} \\
\hline Hayır & $65(71.4)$ & $63(70.8)$ & \\
\hline \multicolumn{4}{|c|}{ Daha önce kullanılan gebelikten korunma yöntemi } \\
\hline Evet & $53(58.2)$ & $61(68.5)$ & \multirow{2}{*}{$0.152 *$} \\
\hline Hayir & $38(41.8)$ & $28(31.5)$ & \\
\hline \multicolumn{4}{|c|}{ En son kullanılan gebelikten korunma yöntemi $(n=114)$} \\
\hline Kondom/prezervatif & $28(52.8)$ & $29(47.5)$ & \multirow{3}{*}{$0.852^{*}$} \\
\hline Hormonal yöntemler & $10(18.9)$ & $13(21.3)$ & \\
\hline Geri çekme & $15(28.3)$ & 19(31.1) & \\
\hline
\end{tabular}

$(*) \mathrm{X}_{\text {Pearson, }}^{2 *}(*) \mathrm{X}_{\text {Yates }}^{2}$

Tablo 3. Kadınların Gebelikle İlişkili Sağlıkı Yaşam Davranış
Tablo 4. Kadınların değişim aşamalarına göre dağılımı

\begin{tabular}{|c|c|c|c|c|c|c|}
\hline \multirow{3}{*}{$\begin{array}{c}\text { Değişim } \\
\text { aşamaları }\end{array}$} & \multicolumn{2}{|c|}{ Girişim $(n=91)$} & & \multicolumn{2}{|c|}{ Kontrol (n=89) } & \\
\hline & Ön-test & Son-test & & Ön-test & Son-test & \\
\hline & $\mathbf{n}(\%)$ & $\mathbf{n}(\%)$ & p değeri & $\mathbf{n}(\%)$ & $\mathbf{n}(\%)$ & p değer \\
\hline \multicolumn{7}{|c|}{ Folik asit kullanımı değişim aşamaları } \\
\hline Düşünme öncesi & 19(20.9) & $5(5.5)$ & \multirow{5}{*}{$\mathrm{p}<0.001$ * } & $25(28.1)$ & $22(24.7)$ & \multirow{5}{*}{$0.521^{*}$} \\
\hline Düşünme & $53(58.2)$ & $30(33.0)$ & & $42(47.2)$ & $37(41.6)$ & \\
\hline Hazırlık & $7(7.7)$ & $28(30.8)$ & & $15(16.9)$ & $20(22.5)$ & \\
\hline Hareket & $11(12.1)$ & $16(17.6)$ & & $6(6.7)$ & $7(7.9)$ & \\
\hline Sürdürme & $1(1.1)$ & $12(13.2)$ & & $1(1.1)$ & $3(3.4)$ & \\
\hline \multicolumn{7}{|c|}{ Düzenli fiziksel aktivite değişim aşamaları } \\
\hline Düşünme öncesi & $10(11.0)$ & $2(2.2)$ & \multirow{5}{*}{$\mathrm{p}<0.001$ * } & $19(21.3)$ & $15(16.9)$ & \multirow{5}{*}{$0.265^{*}$} \\
\hline Düşünme & $54(59.3)$ & $33(36.3)$ & & $42(47.2)$ & $41(46.1)$ & \\
\hline Hazırlık & $7(7.7)$ & $26(28.6)$ & & $9(10.1)$ & $16(18.0)$ & \\
\hline Hareket & $16(17.6)$ & $15(16.5)$ & & $14(15.7)$ & $10(11.2)$ & \\
\hline Sürdürme & $4(4.4)$ & $15(16.5)$ & & $5(5.6)$ & $7(7.9)$ & \\
\hline \multicolumn{7}{|c|}{ Yeterli ve dengeli beslenme değişim aşamaları } \\
\hline Düşünme öncesi & $10(11.0)$ & $4(4.4)$ & \multirow{5}{*}{$\mathrm{p}<0.001$ * } & $17(19.1)$ & $16(18.0)$ & \multirow{5}{*}{$0.815^{*}$} \\
\hline Düşünme & $54(59.3)$ & $32(35.2)$ & & $44(49.4)$ & $41(46.1)$ & \\
\hline Hazırlık & 13(14.3) & $2(28.6)$ & & $17(19.1)$ & $22(24.7)$ & \\
\hline Hareket & $12(13.2)$ & $14(15.4)$ & & $6(6.7)$ & $4(4.5)$ & \\
\hline Sürdürme & $2(2.2)$ & $15(16.5)$ & & $5(5.6)$ & $6(6.7)$ & \\
\hline \multicolumn{7}{|c|}{ Sigarayı Bırakma Değişim Așamaları (Girișim n=10, Kontrol n=20) } \\
\hline Düşünme öncesi & $0(0.0)$ & $0(0.0)$ & \multirow{5}{*}{ ** } & $4(20.0)$ & $1(5.0)$ & \multirow{5}{*}{$* *$} \\
\hline Düşünme & $9(90.0)$ & $4(40.0)$ & & $14(70.0)$ & $14(70.0)$ & \\
\hline Hazırlık & $1(10.0)$ & $4(40.0)$ & & $2(10.0)$ & $4(20.0)$ & \\
\hline Hareket & - & $2(20.0)$ & & - & $1(5.0)$ & \\
\hline Sürdürme & - & - & & - & - & \\
\hline
\end{tabular}

(*)Bowker Test, $(* *)$ Tablodaki gözlerde n sayısının 5 'in altında olması ve bazı gözlerinde boş olması nedeni ile istatistik yapılamamıştır.

Özelliklerine Göre Dağılımı

\begin{tabular}{|c|c|c|c|c|c|c|c|}
\hline \multirow{3}{*}{ Değişkenler } & \multicolumn{2}{|c|}{ Girişim $(\mathrm{n}=91)$} & \multirow{3}{*}{ p değeri } & \multicolumn{2}{|c|}{ Kontrol $(\mathrm{n}=89)$} & \multirow{3}{*}{ p değeri } & \multirow{3}{*}{$\begin{array}{c}\text { Ön testlerin karşılaştırılması } \\
\mathbf{p}^{\dagger}\end{array}$} \\
\hline & Ön-test & Son-test & & Ön-test & Son-test & & \\
\hline & n(\%) & $\mathrm{n}(\%)$ & & n(\%) & $\mathbf{n}(\%)$ & & \\
\hline \multicolumn{8}{|c|}{ Folik asit hakkinda bilgi } \\
\hline $\begin{array}{l}\text { Evet } \\
\text { Havyr }\end{array}$ & $\begin{array}{l}44(48.4) \\
47(51.6)\end{array}$ & $\begin{array}{l}76(83.5) \\
15(16.5)\end{array}$ & $\mathrm{p}<0.001^{*}$ & $\begin{array}{l}59(66.3) \\
30(33.7)\end{array}$ & $\begin{array}{l}61(68.5) \\
28(31.5)\end{array}$ & $0.791 *$ & 0.015 \\
\hline \multicolumn{8}{|c|}{ Folik asit açsından zengin besinleri bilme } \\
\hline $\begin{array}{l}\text { Evet } \\
\text { Hayır }\end{array}$ & $\begin{array}{l}33(36.3) \\
58(63.7)\end{array}$ & $\begin{array}{l}58(63.7) \\
33(36.3)\end{array}$ & $\mathrm{p}<0.001^{*}$ & $\begin{array}{l}33(37.1) \\
56(62.9)\end{array}$ & $\begin{array}{l}31(34.8) \\
58(65.2)\end{array}$ & $0.774 *$ & 0.910 \\
\hline \multicolumn{8}{|c|}{ Düzenli olarak günde 400 mikrogram folik asit kullanma } \\
\hline Evet & $12(13.2)$ & 29(31.9) & \multirow{2}{*}{$\mathrm{p}<0.001^{*}$} & $7(7.9)$ & $13(14.6)$ & \multirow{2}{*}{$0.070^{*}$} & \multirow{2}{*}{$0.358^{* *}$} \\
\hline Hayır & $79(86.8)$ & $62(68.1)$ & & $82(92.1)$ & $76(85.4)$ & & \\
\hline \multicolumn{8}{|c|}{ Düzenli fiziksel aktivite hakkında bilgi } \\
\hline $\begin{array}{l}\text { Evet } \\
\text { Hayır }\end{array}$ & $\begin{array}{l}44(48.4) \\
47(51.6)\end{array}$ & $\begin{array}{l}70(76.9) \\
21(23.1)\end{array}$ & $\mathrm{p}<0.001^{*}$ & $\begin{array}{l}65(73.0) \\
24(27.0)\end{array}$ & $\begin{array}{l}66(74.2) \\
23(25.8)\end{array}$ & $1.000^{*}$ & 0.001 \\
\hline \multicolumn{8}{|c|}{ Uzun süre hareketsiz olmaktan kaçınma } \\
\hline Evet & $54(59.3)$ & $61(67.0)$ & \multirow{2}{*}{$0.265^{*}$} & $62(69.7)$ & $60(67.4)$ & \multirow{2}{*}{$0.774^{*}$} & \multirow{2}{*}{0.148} \\
\hline Hayır & $37(40.7)$ & $30(33.0)$ & & $27(30.3)$ & $29(32.6)$ & & \\
\hline \multicolumn{8}{|c|}{ Düzenli fiziksel aktivite yapma } \\
\hline Evet & $36(39.6)$ & $45(49.5)$ & \multirow{2}{*}{$0.064^{*}$} & $39(43.8)$ & $38(42.7)$ & \multirow{2}{*}{$1.000^{*}$} & \multirow{2}{*}{0.562} \\
\hline Hayır & $55(60.4)$ & $46(50.5)$ & & $50(56.2)$ & $51(57.3)$ & & \\
\hline \multicolumn{8}{|c|}{ Düzenli kahvaltı yapma } \\
\hline Evet & $61(67.0)$ & $66(72.5)$ & \multirow{2}{*}{$0.227^{*}$} & $67(75.3)$ & $66(74.2)$ & \multirow{2}{*}{$1.000^{*}$} & \\
\hline Hayır & $30(33.0)$ & $25(27.5)$ & & $22(24.7)$ & $23(25.8)$ & & 0.222 \\
\hline & & & Öğ̈i & aya dikkat & & & \\
\hline $\begin{array}{l}\text { Evet } \\
\text { Hayır }\end{array}$ & $\begin{array}{l}44(48.4) \\
47(51.6)\end{array}$ & $\begin{array}{l}53(58.2) \\
38(41.8)\end{array}$ & $0.093^{*}$ & $\frac{43(48.3)}{46(51.7)}$ & $\frac{48(53.9)}{41(46.1)}$ & $0.332 *$ & 0.996 \\
\hline & & & ve sonrasis & & & & \\
\hline Evet & $64(70.3)$ & $77(84.6)$ & $0.007 *$ & $71(79.8)$ & $75(84.3)$ & $0.344^{*}$ & $0.197^{* *}$ \\
\hline Hayır & $27(29.7)$ & $14(15.4)$ & & $18(20.2)$ & $14(15.7)$ & & \\
\hline & & Yeterli ve den & lek için uyg & kanlık (örı & altida yun & vb.) & \\
\hline Evet & $57(62.6)$ & $65(71.4)$ & & $54(60.7)$ & $52(58.4)$ & $0.804 *$ & \\
\hline Hayır & $34(37.4)$ & $26(28.6)$ & $0.077^{*}$ & $35(39.3)$ & $37(41.6)$ & & 0.787 \\
\hline & & & esin grupla & bir diyetle & e dikkat e & & \\
\hline Evet & $51(56.0)$ & $60(65.9)$ & $0064 *$ & $56(62.9)$ & $54(60.7)$ & $0.804 *$ & 0347 \\
\hline Hayır & $40(44.0)$ & $31(34.1)$ & & $33(37.1)$ & $35(39.3)$ & & \\
\hline & & & & nma durun & & & \\
\hline $\begin{array}{l}\text { Evet } \\
\text { Hayir }\end{array}$ & $10(11.0)$ & $\begin{array}{c}9(9.9) \\
82(90.1)\end{array}$ & $1.000^{*}$ & $\begin{array}{l}19(21.3) \\
707877\end{array}$ & $\begin{array}{l}18(20.2) \\
71(79.8)\end{array}$ & $1.000^{*}$ & $0.092 * *$ \\
\hline Hayır & $81(89.0)$ & $82(90.1)$ & & lanma durt & & & \\
\hline $\begin{array}{l}\text { Evet } \\
\text { Hayır }\end{array}$ & $\begin{array}{l}49(53.8) \\
42(46.2)\end{array}$ & $\begin{array}{l}45(49.5) \\
46(50.5)\end{array}$ & $0.125^{*}$ & $\begin{array}{l}45(50.6) \\
44(49.4)\end{array}$ & $\begin{array}{l}44(49.4) \\
45(50.6)\end{array}$ & $1.000^{*}$ & 0.659 \\
\hline
\end{tabular}

(*)McNemar Test, $(\dagger) \mathrm{X}_{\text {Pearson }}^{2}$ testi; başlangıçta girişim ve kontrol gruplarının karşılaştırılması, $(* *) \mathrm{X}_{\text {Yates }}^{2}$ testi 
Tablo 5. Kadınların Genel Öz-Yeterlilik (GÖYÖ), Sağlıklı Yaşam Biçimi Davranışları Ölçeği (SYBDÖ-II) ve alt boyutlarının puan ortalamalarına göre dağılımı

\begin{tabular}{|c|c|c|c|c|c|c|c|}
\hline \multirow{3}{*}{ Ölçekler ve alt boyutları } & \multicolumn{2}{|l|}{ Girişim (n=91) } & & \multicolumn{2}{|l|}{ Kontrol (n=89) } & & \multirow{2}{*}{$\begin{array}{l}\text { Ön testlerin } \\
\text { karşılaştırılması }\end{array}$} \\
\hline & Ön-test & Son-test & & Ön-test & Son-test & & \\
\hline & Ort \pm SS & Ort \pm SS & p değeri * & Ort \pm SS & Ort \pm SS & p değeri * & $\mathbf{p}_{\dagger}^{\dagger}$ \\
\hline GÖYÖ & $31.17 \pm 5.33$ & $33.57 \pm 4.64$ & $<0.001$ & $31.60 \pm 5.18$ & $31.15 \pm 4.64$ & 0.323 & 0.583 \\
\hline SYBDÖ-II & $134.42 \pm 24.01$ & $147.68 \pm 21.36$ & $<0.001$ & $131.53 \pm 22.13$ & $134.67 \pm 19.59$ & 0.029 & 0.403 \\
\hline $\mathrm{p}^{* *}$ & $\mathrm{p}<0.001$ & 0.001 & & 0.001 & 0.019 & & \\
\hline Sağlık sorumluluğu & $22.79 \pm 5.55$ & $25.06 \pm 5.45$ & $<0.001$ & $21.64 \pm 4.97$ & $22.47 \pm 5,01$ & 0.030 & 0.145 \\
\hline Fiziksel aktivite & $17.24 \pm 5.91$ & $20.60 \pm 5.49$ & $<0.001$ & $17.05 \pm 5.16$ & $17.44 \pm 4.76$ & 0.344 & 0.823 \\
\hline Beslenme & $22.16 \pm 5.00$ & $23.87 \pm 4.97$ & 0.015 & $21.66 \pm 3.65$ & $21.79 \pm 4.51$ & 0.816 & 0.443 \\
\hline Manevi gelişim & $26.72 \pm 4.88$ & $28.45 \pm 4.69$ & $<0.001$ & $26.10 \pm 4.92$ & $26.82 \pm 4.26$ & 0.035 & 0.009 \\
\hline Kişilerarası ilişkiler & $26.08 \pm 4.21$ & $27.72 \pm 4.32$ & $<0.001$ & $25.91 \pm 4.93$ & $26.32 \pm 4.50$ & 0.248 & 0.795 \\
\hline Stres yönetimi & $19.41 \pm 4.33$ & $21.95 \pm 4.93$ & $<0.001$ & $19.16 \pm 3.87$ & $19.80 \pm 3.88$ & 0.022 & 0.685 \\
\hline
\end{tabular}

$(*)$ Bağımlı grupta t testi, (**) GÖYÖ ve SYBDÖ-II arasında korelasyon analizi, (†)Bağımsız grupta t testi; başlangıçta girişim ve kontrol gruplarının karşılaştırılması.

Girişim grubunda yer alan kadınların; folik asit kullanma, düzenli fiziksel aktivite uygulama, yeterli ve dengeli beslenme açısından değişim aşamaları ön-son test sonuçlarına göre aralarında bulunan farkın istatistiksel olarak da anlamlı olduğu saptanmıştır $(p<0.05)$. Girişim Grubunda yer alan kadınlarda, eğitim sonrası hazırlık/hareket/ sürdürme aşamalarında folik asit kullanımı açısından \%40.7'lik, düzenli fiziksel aktivite açısından \%31.9'luk, yeterli ve dengeli beslenme açısından \%29.1'lik artış olduğu saptanmıştır.

Girişim ve kontrol grubunda yer alan kadınlardan 30'u sigara kullandığını ifade etmiştir. Sigara bırakma değişim aşamalarında, gözlerde yer alan birey sayısının 5'ten az olması (boş göz) nedeni ile p değeri hesaplanamamıştır. Ancak sigara bırakma değişim aşamaları yüzde olarak incelendiğinde farklılıklar olduğu görülmektedir.

Kontrol grubunda yer alan kadınların; folik asit kullanma, düzenli fiziksel aktivite uygulama, yeterli ve dengeli beslenme açısından önson test sonuçlarına göre değişim aşamalarındaki farkın istatistiksel olarak anlamlı olmadığı saptanmıştır ( $\mathrm{p}>0.05)$ (Tablo 4).

Girişim grubunda yer alan kadınların ön-son test sonuçlarına göre; GÖYÖ, SYBDÖ-II ve tüm alt boyutlarının puan ortalamaları açısından aralarında bulunan farkın istatistiksel olarak da anlamlı olduğu saptanmıștır $(\mathrm{p}<0.05)$.

Kontrol grubunda yer alan kadınların ön-son test sonuçlarına göre; SYBDÖ-II ve sağlık sorumluluğu, manevi gelişim, stres yönetimi alt boyutlarının puan ortalamaları açısından aralarında bulunan farkın istatistiksel olarak da anlamlı olduğu saptanmıştır ( $p>0.05$ ).

Girişim ve kontrol gruplarında yer alan kadınların ön-son test sonuçlarına göre GÖYÖ ve SYBDÖ-II toplam puanları arasında ilişki olduğu saptanmıştır $(\mathrm{p}<0.05)$ (Tablo 5).

\section{Tartışma}

Bu çalışmada kadınların çoğunun 18-35 yaş grubunda oldukları saptanmıştır. Bu sonuçlar yapılan çalışmalar ile benzerlik (kadınlar 20 ila 35 yaş arasında) göstermektedir (32-34). Bu ve diğer çalışmalarda da görüldüğü gibi prekonsepsiyonel bakım alan kadınlar genç ve üreme çağında kadınlardır. Girişim ve kontrol gruplarında yer alan kadınların yaklaşık dörtte üçü normal kiloludur. Koyucu ve arkadaşları tarafından yapılan çalışma ile kadınların yarısından fazlası (\%56.1) zayıf ve normal kilolu olarak sınıflandırılmıştır (33). Kadınların gebelik öncesi BKİ değerinin normal sınırlar içinde olması, üreme fonksiyonlarının sağlıklı bir biçimde devam edebilmesini ve gebelikte olası sorunların çıkmasını önler $(35,36)$. BKİ değeri gebelikte ortaya çıkabilecek problemler ve alınabilecek önlemler açısından önemli bir bulgudur. Çalışmamızda girişim $(\% 67.0)$ ve kontrol (\%66.3) grubunda yer alan kadınların çoğunun yükseköğrenim gördükleri saptanmıştır. Bu sonuçlar yurt dışında yapılan çalışma sonuçları ile benzerdir $(37,38)$. Ancak çalışmamızın aksine ülkemizde yapılan çalışmalarda kadınların çoğunun ortaöğretim düzeyinde eğitim aldıkları belirtilmektedir (32,33). Türkiye'de kadınların öğrenim düzeylerinin bölgelere göre farkl1lıklar gösterdiğini tanımlayan çalışmalar da olup, bu sonuçların, çalışmanın yapıldığı bölgenin eğitim düzeyi yüksek ailelerin oturduğu bir bölge olmasından ya da araştırmaya katılmak isteyen kadınların eğitim düzeylerinin yüksek olmasından kaynaklandığı düşünülebilir (39). Bu çalışmada kadınların yaklaşık dörtte üçünün aylık geliri orta düzeyde (gelir gidere denk) olup benzer olarak Koyucu ve arkadaşları kadınların \%59.0'unun orta gelir düzeyine sahip olduklarını belirtmiştir (33).

Bu çalışma ile kadınların yarısından fazlasının reçetesiz/danışmadan ilaç (ağrı kesici, öksürük şurubu, vs.) kullanmakta olduğu, çiğ et yeme/ çiğ ete temas etmekte ve pasif içiciliğe maruz kaldıkları belirlenmiştir. İtalya'da yapılan bir çalışma ile pasif içiciliğe maruz kalma oranları, bölgelere göre farklılık göstermekle birlikte tüm araştırma grubunda bu oran \%14.3 olarak saptanmıştır (40). Toplumumuzda kadınların pasif içiciliğe maruz kalma durumları oldukça fazladır. Yapılan bir çalışma ile gebe kadınların reçetesiz ilaç kullanma (\%43.9) nedenleri sorgulandığında; ateş/sık görülen soğuk algınlığı semptomları, baş ağrısı/migren, sindirim bozuklukları gibi nedenler ile kullandıkları belirlenmiştir (41). Gebelikte reçetesiz ilaç kullanmanın hem kadın hem de fetüs açısından risk oluşturduğu, özellikle ilk trimesterde aspirin ve türevlerini kullanmanın nadiren de olsa fetüste karın duvarı defekti olan gastroşizis riskini arttırabileceği gösterilmiştir $(42,43)$. Yapılan çalışmalar ile kadınların gebelik sırasında reçetesiz satılan ilaçları kullanma durumlarının daha yüksek olduğu ve çoğu kadının Folik Asit ve multivitamin dışında bitkisel destek aldığı belirlenmiştir $(44,45)$. Gebelik oluşmadan önce dozu düzenlenmeyen (antiepileptik ilaçlar gibi) veya gebelik sırasında reçetesiz olarak kullanılan ilaçlar, gebelik fark edilene kadar geçen süre zarfında fetal açıdan malformasyonlara neden olabilir $(46,47)$.

Prekonsepsiyonel Dönemdeki Kadınların Sağlık Davranışları Değişim Aşamaları - Erkal Aksoy ve Özentürk. 
Toksoplazmosiz enfeksiyonu çiğ et, yeni enfekte olmuş kedilerin dışkısı ve anneden bebeğe geçiş gibi birçok yoldan hastalığa neden olabilmektedir. Amerika Birleşik Devletlerinde yetişkin kadınların yaklaşık üçte birinde toksoplazmosiz antikorlarının bulunduğu, bu durumun gebelik sirasında konjenital enfeksiyona neden olabilecek primer anne risk faktörünü oluşturduğu belirtilir (48). Bu çalışma ile kadınların toksoplazmosiz antikorları değerlendirilmemiş olmakla birlikte yarıdan fazla kadının çiğ ete temas etme/çiğ et yeme durumu olduğu belirlenmiştir.

Kontrol grubunda yer alan kadınların $\% 68.5$ 'i, girişim grubunda yer alan kadınların \%58.2'si daha önce gebelikten korunmak için herhangi bir yöntem kullandıklarını belirtmişlerdir. Girişim ve kontrol grubundaki kadınların benzer olarak modern yöntemlerden kondom/prezervatif, hap/oral kontraseptif/hormon iğneleri kullanmış olduğu geleneksel yöntemlerden ise geri çekme yönteminin tercih edildiği görülmektedir. Bu çalışma ile Avrupa ülkelerinde yapılan çalışma sonuçları karşılaştırıldığında modern kontraseptif (kondom/ prezervatif, hap/oral kontraseptif/hormon iğneleri) kullanım oranları benzerlik göstermektedir (49,50). Geleneksel yöntem olarak kullanılan geri çekme yöntemi kullanma oranı Türkiye Nüfus ve Sağlık Araştırmaları (TNSA) 2018 yılı verilerine göre \%20 olarak belirlenmiş olup, yapılan bir çalışma ile geri çekme yönteminin benzer oranlarda kullanıldığı belirlenmiştir (39,51). Buldurucu ve Yazıcı (2015) tarafından yapılan çalışma ile geri çekme yöntemi kullanma nedenlerinin; kullanımının kolay olması, eşinin tercih etmesi, diğer yöntemlere göre ucuz olması, dini yönden tercih edilmesi ve kısa süre sonra bebek sahibi olma düşüncesi şeklinde ifade edildiği belirtilmiştir (51). Bu çalışmada yer alan tüm kadınların dörtte birinin geleneksel bir yöntem olan geri çekme yöntemini tercih ettikleri saptanmış olup, bu sonucun her iki grupta yer alan kadınların gebelik düşünmelerinin yanı sıra yaşadıkları bölgenin kültürel yapısından da kaynaklanmış olabileceğini düşündürmektedir. Kadınların geri çekme yöntemini kullanmaları plansız gebeliklerin oluşmasına neden olabileceği için kadınlara, prekonsepsiyonel dönemde, aile planlaması yöntemleri konusunda danışmanlık verilmesi oldukça önemlidir.

$\mathrm{Bu}$ çalışma ile girişim grubunda yer alan kadınlara verilen gebeliğe hazırlık eğitiminin; folik asit ve folik asit açısından zengin besinleri tanıma, düzenli olarak günde 400 mikrogram folik asit kullanma, düzenli fiziksel aktivite yapma, ögün sırası ve sonrası su içme açısından değişikliklere neden olduğu saptanmıştır. Kontrol grubunda yer alan kadınlarda bu farklılıklar görülmemiştir. Bu sonuçlara dayanarak gebeliğe hazırlık eğitiminin etkili olduğu söylenebilir. Yapılan bir çalışma ile tek bir prekonsepsiyonel danışmanlık oturumunun, folik asit kullanımı ve farkındalığın artırılmasında etkili olduğu gösterilmiştir (11). Yapılan diğer bir çalışma ile çoğu kadının (\%65.6) Folik asiti gebelikten önce duyduğu, ancak sadece \%24.6'sının gebelikten önce folik asit kullandığı, gebelikten önce folik asit kullanan kadınların ise yüksek eğitimli oldukları saptanmıştır (52). Bu çalışma ile girişim grubunda yer alan kadınların \%31.9'unun düzenli olarak günde 400 mikrogram folik asit kullandıkları belirlenmiştir.

TTM bireylerin davranış değişimlerini incelemek ve bulunduğu aşamaya yönelik müdahalelerde bulunmak için kullanılmaktadır. Prekonsepsiyonel dönem; yaşamın birçok alanında kadına davranış değişikliği oluşturma ve sağlığını geliştirme firsatı tanır. Literatürde prekonsepsiyonel bakım kapsamında yer alan konulara yönelik TTM ile entegre edilmiş çalışmalar bulunmaktadır $(53,54)$. Bu çalışma ile girişim grubunda yer alan kadınların folik asit kullanımı değişim aşamaları açısından ön-son test sonuçlarına göre eğitim sonrası hazırlık/hareket/sürdürme aşamalarında \%40.7'lik artış olduğu saptanmıştır. Yapılan bir çalışma ile web ortamında folik asit hakkında eğitim verilerek değişim aşamaları değerlendirilmiş olup, eğitim verilen kadınların ön-son test sonuçlarına göre hareket ve sürdürme aşamalarında \%22.0'lık artış olduğu, eğitim verilmeyen kadınlarda ise bu artışın \%10.0 olduğu saptanmıştır (53). Bu çalışma ile eğitimin birebir verilmiş olmasının girişim grubunda yer alan kadınlarda folik asit kullanımı değişim aşamalarını daha yüksek oranda etkilemiş olmasından kaynaklandığını, kontrol grubunda yer alan kadınların ise gebelik düşünmeye başlamaları ve/veya bu çalışmaya katılmaları nedeni ile folik asit hakkında bilgi arayışına girmiş olabileceklerinden kaynaklandığını düşündürmektedir. Çalışmamızda girişim grubundaki kadınların \%59.3'unun düzenli fiziksel aktivite değişim aşamaları açısından eğitim öncesi düşünme aşamasında olup, eğitim sonras1 \%28.6'sının hazırlık, \%16.5'inin hareket, \%16.5'inin sürdürme aşamalarında olduğu saptanmıştır. Bu sonuçlar, fiziksel aktivitenin önem kazandığı günümüzde, kadınların prekonsepsiyonel dönemde fiziksel aktiviteye teşvik edilmelerinin konuya yönelik hassasiyeti pekiştirdiği düşünülebilir. Genel popülasyonda düzenli fiziksel aktivite konusunda yapılan bir çalışma ile çoğu kadının inaktif aşamada (\%20.2'sinin düşünme öncesi, \%17.5'inin düşünme, \%32.9'unun hazırlık aşamasında) olduğu belirlenmiştir (55). Bu çalışma ile kadınların eğitim sonrası aktif aşamada yer aldıkları görülmekte olup, bu çalışmaya benzer bir çalışma ile kadınlara fiziksel aktivite konusunda eğitim verildikten üç ve altı ay sonra değişim aşamaları değerlendirilerek eğitim verilen-verilmeyen grup arasında fark olduğu istatistiksel olarak da anlamlı bulunmuştur (56). Girişim grubundaki kadınlar yeterli ve dengeli beslenme değişim aşamaları açısından incelendiğinde eğitim öncesi \%59.3'u düşünme aşamasında iken, eğitim sonrası \%28.6'sının hazırlık, \%15.4'ünün hareket, \%16.5'inin ise sürdürme aşamasında oldukları belirlenmiştir. Yapılan bir çalışma ile gebe kalmayı düşünen fazla kilolu ve obez kadınlar incelenmiş, kadınların sağlık inanç modeli ile beslenme ve fiziksel aktivite değişim aşamaları arasında ilişki olduğu saptanmıştır (54). Diğer bir çalışma ile beslenme ve fiziksel aktivite hakkında eğitim verilen infertil ve obez kadınlar arasında düşünme, hazırlık ve hareket aşamalarındaki kadınların, sürdürme aşamasındaki kadınlara göre daha fazla ağırlık kaybettikleri ve adım sayılarının arttı̆̆ belirlenmiştir (19).

Literatürde, sigara bırakma konusunda bu çalışmaya benzer TTM temelli düzenlenen eğitimlerin, görünürde bir fark yarattığı, ancak istatistiksel olarak anlamlı olmadığını belirten çalışmalar yer almaktadır $(57,58)$. Bu çalışma ile girişim ve kontrol grubunda yer alan kadınlar arasında 30 kadının sigara kullandıkları belirlenmiş, değişim aşamalarında sayısal olarak farklılıklar gözlenmiş olmakla birlikte bulunan farkın istatistiksel olarak anlamlı olmadığ 1 saptanmıştır. Yapılan bir çalışma ile gebe kadınların gebelikleri sırasında sigarayı bırakmaları ele alınmış, primipar ve multipar gebelerin değişim aşamaları arasında fark olmadığı, çoğu gebenin düşünme öncesi aşamada yer aldığı belirlenmiştir (59).

$\mathrm{Bu}$ çalışma ile gebeliğe hazırlık eğitiminin kadınların ölçek puan ortalamalarında değişime neden olduğu, kadınların özyeterlilik düzeyini arttırdığı, buna bağlı olarak sağliklı yaşam biçimi davranışlarının da arttığı belirlenmiştir. Girişim grubundaki kadınlarda ön-son test sonuçlarına göre ölçek puan ortalamaları arasında fark olduğu, kontrol grubunda yer alan kadınlarda ise önson test sonuçlarına göre fiziksel aktivite, beslenme ve kişilerarası 
ilişkiler ölçek alt boyutlarında fark olmadığı belirlenmiştir. Bu çalışmaya benzer bir çalışma ile prekonsepsiyonel bakım konusunda danışmanlık verilen kadınların sağlık sorumluluğu, fiziksel aktivite, stres yönetimi ve beslenme alt boyutları ve aynı zamanda sağlıklı yaşam biçimi davranışları ölçek toplam puanlarının arttığı saptanmıştır (60). Kontrol Grubunda yer alan kadınlarda ölçek toplam puanı ve diğer alt boyut puanlarında fark bulunması, kadınların gebelik planlamaya bağlı istemli davranış değişikliğine gitmiş olabileceklerini düşündürmektedir. Çalışmamızda girişim ve kontrol gruplarındaki kadınların ön-test sonuçlarına göre fiziksel aktivite alt boyutunda en düşük puan ortalamasına sahip oldukları, son-test sonuçlarına göre girişim grubundaki kadınların puan ortalamasının arttığı ve bu artışın kontrol grubunda yer alan kadınlara göre daha yüksek olduğu saptanmıştır. Bu çalışma ile elde edilen sonuçlar literatür ile benzerlik göstermektedir (60-62).

\section{Araştırmanın Sınırılılıkları}

Araştırmaya, Türkiye'nin Konya ili Selçuklu ilçesine bağlı bir ASM'nden bakım alan, gebelik düşünen ve araştırmaya katılmayı kabul eden kadınlar alınmıştır. Bu neden ile elde edilen sonuçlar araştırma bölgesine genellenebilir. Kadınların iletişim bilgileri kurumun gizlilik politikası nedeniyle elde edilememiş olup evren sayısı belirlenememiştir. Araştırmacı kurumda bulunduğu sırada gelen kadınlar ile görüşmüş, araştırmaya alınma kriterlerine uyan ve katılmayı kabul eden kadınlar çalışmaya almıştır. Araştırma girişiminin doğası gereği randomizasyon sırasında tek körleme yapılabilmiştir. Araştırma deseni gereği, her kadın için eğitimden sekiz hafta sonra sonlandırılmıştır, ancak kadınlar gebe kalana kadar izlemlerin sürdüğü uzunlamasına çalışmalar planlanabilir.

\section{Sonuç}

$\mathrm{Bu}$ çalışmada girişim grubundaki kadınlara gebeliğe hazırlık eğitimi verildi. Kadınların eğitim sonrası folik asit hakkında bilgi, folik asit açısından zengin besinler hakkında bilgi, düzenli olarak günde 400 mikrogram folik asit kullanma, düzenli fiziksel aktivite hakkında bilgi, öğün sırası ve sonrası su içme durumlarında artış olduğu belirlenmiştir. Kontrol grubunda yer alan kadınların ise gebelikle ilişkili sağlıklı yaşam davranış özelliklerinde sekiz haftalık süreç boyunca bir değişiklik olmadığı görülmektedir. Prekonsepsiyonel dönemde verilen gebeliğe hazırlık eğitiminin, folik asit kullanımı, düzenli fiziksel aktivite, yeterli ve dengeli beslenme değişim aşamaları açısından etkili olduğu, ölçek puan ortalamalarında anlamlı artış sağladığı tespit edilmiştir. Çalışmamız sonucunda yapılan girişimin olumlu etkisi olduğu saptanmıştır.

\section{Etik Açıklamalar}

Araştırmaya başlamadan önce Selçuk Üniversitesi Sağlık Bilimleri Fakültesi Girişimsel Olmayan Çalışmalar Etik Kurulu'ndan 2018/71 karar sayı ile etik izin alınmıştır. Clinical trials kaydı yapılmış, kayıt numarası (NCT03893084)'tür. Konya İl Sağlı Müdürlüğü ve Selçuklu/Konya ilçesinde olan bir aile sağlığı merkezinin sorumlu hekimlerinden ve araştırmada kullanılan ölçeklerin geçerlik ve güvenirlik çalışmalarını yapan sorumlu yazarlardan e-mail yoluyla, gerekli izinler alınmıştır. Araştırmaya katılan kadınların aydınlatılmış onamı alınmıştır.

\section{Teșekkürler}

Zaman ayırıp çalışmaya katılan tüm kadınlara çok teşekkür ederiz. Bu makale doktora tezinden üretilmiştir. Makalenin özeti 18-19 Nisan 2019 tarihinde yapılan 3. Uluslararası Kadın Çocuk Sağlı̆̆ ve Eğitimi Kongresinde (Trabzon/Türkiye) sözel bildiri olarak sunulmuştur.

\section{Kaynaklar}

1.Darmstadt GL, Bhutta ZA, Cousens S, et al. Evidence-based, cost-effective interventions: how many newborn babies can we save? Lancet 2005;365(9463):977-88.

2.Bhutta ZA, Das JK, Bahl R, et al. Can available interventions end preventable deaths in mothers, newborn babies, and stillbirths, and at what cost? Lancet 2014;384(9940):34770 .

3.Doğaner G, Gölbaş1 Z. Preconceptional Consultancy. STED 2011;20(5):215-21.

4.WHO. Preconception care: Maximizing the gains for maternal and child health. Switzerland; 2013. Available at: https://www.who.int/maternal_child_adolescent/ documents/preconception_care_policy_brief.pdf. Accessed August 27, 2020.

5.Çoşkun A. The Place and Importance of Preconception Careand Counseling in Women's Lives. Hemşirelikte Eğitim ve Araştırma Dergisi 2011;8(3):8-15.

6.Witt WP, Wisk LE, Cheng ER, et al. Preconception mental health predicts pregnancy complications and adverse birth outcomes: a national population-based study. Matern Child Health J 2012;16(7):1525-41.

7.Bish CL, Farr S, Johnson D, et al. Preconception health of reproductive aged women of the Mississippi River delta. Matern Child Health J 2012;16 Suppl 2:250-7.

8.Stern J. Preconception Health and Care: A Window of Opportunity. BMC Pregnancy Childbirth 2015;19(12):1-72.

9.Dean S V, Lassi ZS, Imam AM, et al. Preconception care: nutritional risks and interventions. Reprod Health 2014;11(Suppl(S3):1-15.

10.ACOG. ACOG Committee Opinion number 313, September 2005.The Importance of Preconception Care in the Continuum of Women's Health Care. Obstet Gynecol. 2005;106(3):665-6.

11.de Weerd S, Thomas CM, Cikot RJ, et al. Preconception counseling improves folate status of women planning pregnancy. Obstet Gynecol 2002;99(1):45-50.

12.Lu MC. Recommendations for preconception care. American Family Physician 2007;76(3):397-400

13.AAP, ACOG. Guidelines for Perinatal Care. 7th ed. Riley A.R. LE. S, editor. Washington: AmericanAcademy of Pediatrics; American College of Obstetricians and Gynecologists; 2012. p. 95-168.

14.Freda MC, Moos MK, Curtis M. The history of preconception care: evolving guidelines and standards. Matern Child Health J 2006;10(5 Suppl):S43-52.

15.Lassi ZS, Dean S V, Mallick D, et al. Preconception care: delivery strategies and packages for care. Reprod Health 2014;11(Suppl 3):S7.

16.WHO. Meeting to develop a global consensus on preconception care to reduce maternal and childhood mortality and morbidity. Geneva: World Health Organization; 2013.

17.Ata KK, Şahin NH. The Effect of Pregestational Body Mass Index on Prenatal And Neoanatal Outcomes. Medical Bulletin of Zeynep Kamil 2015;46(4):112-7.

18.Jelsma JG, van Leeuwen KM, Oostdam N, et al. Beliefs, Barriers, and Preferences of European Overweight Women to Adopt a Healthier Lifestyle in Pregnancy to Minimize Risk of Developing Gestational Diabetes Mellitus: An Explorative Study. J Pregnancy 2016;2016:3435791.

19.Karsten MDA, van Oers AM, Groen H, et al. Determinants of successful lifestyle change during a 6-month preconception lifestyle intervention in women with obesity and infertility. Eur J Nutr 2019;58:2463-75.

20.Glanz K, Rimer BK, Viswanath K. Health behavior and health education: theory, research, and practice. 4th ed. Rimer BK, editor. Modelsof indidual health behavior United States of America: John Wiley \& Sons; 2008. p. 41-4.

21.Velicer WF, Prochaska JO, Fava JL, et al. Using the Transtheoretical Model for Population-based Approaches to Health Promotion and Disease Prevention. Homeostasis in Health and Disease 2000;40:174-95.

22.Brewer N, Rimer B. Perspectives on Health Behavior Theories That Focus on Individuals. In: Glanz K, Rimer B, Viswanath K, editors. Health Behavior and Health Education. 4th Editio. United States of America: A Wiley; 2008. p. 149-162.

Prekonsepsiyonel Dönemdeki Kadınların Sağlık Davranışları

Değişim Aşamaları - Erkal Aksoy ve Özentürk. 
23.Prochaska JO, DiClemente CC. Transtheoretical therapy: toward a more integrative model of change. Psychother Theory Res Pract. 1982;19:276-88

24.WHO. Health topics. Health education. WHO; 2018. Available from: http://www.who. int/topics/health_education/en/. Accessed August 27, 2020.

25.Random.Org. Random Sequence Generator. Vol. 2018. Ireland; 2018. Available from https://www.random.org/sequences/. Accessed August 27, 2020.

26.Akın B, Koçoğlu D. Randomize Kontrollü Deneyler. Hacettepe Üniversites Hemşirelik Fakültesi Dergisi. 2017;4(1):73-92.

27.Kanık EA, Taşdelen B, Erdoğan S. Klinik Denemelerde Randomizasyon. Marmara Medical Journal. 2011;24:149-55.

28. Walker SN, Sechrist KR, Pender NJ. The Health-Promoting Lifestyle Profile: development and psychometric characteristics. Nurs Res 1987;36(2):76-81.

29.Bahar Z, Beșer A, Gördes N, et al. Sağlıklı Yaşam Biçimi Davranışları̈Ölçeği II'ni Geçerlik ve Güvenirlik Çalışması. CÜ Hemşirelik Yüksekokulu Dergisi 2008;12(1):1-13.

30.Schwarzer R, Jerusalem M. Generalized Self-Efficacy scale. Weinman J, Wrigh S, Johnston M, editors. Measures in health psychology: A user's portfolio. Causal and control beliefs. UK: NFER-NELSON: Windsor; 1995. p. 35-7.

31.Aypay A. The Adaptation Study of General Self-Efficacy (GSE) Scale to Turkish. Inonu University Journal of the Faculty of Education 2010;11(2):113-31.

32.Arslan H, Özkan A. Evaluation of women in preconceptional period. Zeynep Kamil Tıp Bülteni 2005;36(2):65-71

33.Koyucu RG, Tosun Y, Katran B. Preconceptional counselling needs among women of reproductive age. JAREN 2017;3(3):116-21.

34.Akkoca AN, Kurt RK, Karapınar OS, Özler S, Özer C. Folic acid use and knowledge about among women in reproductive age. Turkish journal of family medicine and primary care (TJFMPC) 2014;8(2):35-8

35.Hanson MA, Bardsley A, De-Regil LM, et al. The International Federation of Gynecology and Obstetrics (FIGO) recommendations on adolescent, preconception, and maternal nutrition: "Think Nutrition First." International Journal of Gynecology \& Obstetrics 2015;131:S213-53.

36.Yanıkkerem E. Effects of obesity on women's health. Journal of Health Sciences of Kocaeli University 2017;3(1):37-43

37.Joyce C, Keraka M, Njagi J. Assessment of the knowledge on preconception care among women of reproductive age in Ruiru sub-county, Kiambu County, Kenya. Global Journal of Health Science (GJHS) 2018;3(1):82-100.

38. Chuang CH, Velott DL, Weisman CS. Exploring knowledge and attitudes related to pregnancy and preconception health in women with chronic medical conditions. Matern Child Health J 2010;14(5):713-9.

39.TPHR. 2018 Turkish Population and Health Researches. Ankara, Turkey: Hacettepe University Institute of Population Studies, T.C. Presidential Strategy and Budget Presidency and TÜBİTAK; 2019.

40.Mastroiacovo P, Nilsen RM, Leoncini E, Gastaldi P, Allegri V, Boiani A, et al. Prevalence of maternal preconception risk factors: an Italian multicenter survey. Ital J Pediatr 2014;40:91

41.Navaro M, Vezzosi L, Santagati G, et al. Knowledge, attitudes, and practice regarding medication use in pregnant women in Southern Italy. PLoS One 2018;13(6):e0198618

42.Lo WY, Friedman JM. Teratogenicity of recently introduced medications in human pregnancy. Obstet Gynecol 2002;100(3):465-73

43. Werler MM, Sheehan JE, Mitchell AA. Maternal medication use and risks of gastroschisis and small intestinal atresia. Am J Epidemiol 2002;155(1):26-31.

44.Werler MM, Mitchell AA, Hernandez-Diaz S, et al. Use of over-the-counter medications during pregnancy. Am J Obstet Gynecol 2005;193(3 Pt 1):771-7.

45.Tsui B, Dennehy CE, Tsourounis C. A survey of dietary supplement use during pregnancy at an academic medical center. Am J Obstet Gynecol 2001;185(2):433-7.

46.Sarıkaya E, Çayırtepe Z. Gebelikte Farmakovijilans ve Teratojenisite. Ankara: Türkiye Anne, Çocuk ve Ergen Sağlığı Enstitüsü; 2018.

47.Aslan S, Çoşkun AM, Oral G. Management and Care of Epilepsy During Pregnancy, Birth and Postpartum. Zeynep Kamil Tıp Bülteni. 2018;49(1):117-25.

48.Coonrod D V, Jack BW, Stubblefield PG, et al. The clinical content of preconception care: infectious diseases in preconception care. Am J Obstet Gynecol 2008;199(6 Suppl 2):S296-309.

49.Hibbert EJ, Chalasani S, Kozan P, et al. Preconception care and contraceptive use among Australian women with diabetes mellitus. Australian Journal of General Practice

\section{8;47(12):877-82}

50.Shrestha BD, Ali M, Mahaini R, et al. A review of family planning policies and services in WHO Eastern Mediterranean Region Member States. Eastern Mediterranean Health Journal. 2019;25(2):127-33

51.Buldurucu S, Yazıcı S. Reasons for couples to prefer withdrawal method. HSP 2015;2(2):156-66

52.Kim J, Yon M, Kim C, et al. Preconceptional use of folic acid and knowledge about folic acidamong low-income pregnant women in Korea. Nutrition Research and Practice 2017;11(3):240-6.

53.Milan JE, White AA. Impact of a stage-tailored, web-based intervention on folic acidcontaining multivitamin use by college women. Am J Health Promot 2010;24(6):388-95.

54.Malverdy Z, Kazemi A. Health beliefs and stages of changes to improve behaviors among obese and overweight women undergoing preconception care. Iran J Nurs Midwifery Res 2016;21(6):595-600.

55.Shaye ZA, Bazzaz MM, Vakili V. A trans-theoretical approach to physical activity profile in general population of Mashhad. GJHS 2015;7(7):46-54

56.Pirzadeh A, Mostafavi F, Ghofranipour F, et al. Applying Transtheoretical Model to Promote Physical Activities Among Women. Iran J Psychiatry Behav Sci 2015;9(4):e1580

57.Velicer WF, Prochaska JO, Fava JL, et al. Interactive versus noninteractive interventions and dose-response relationships for stage-matched smoking cessation programs in a managed care setting. Health Psychol 1999;18(1):21-8.

58.Aveyard P, Massey L, Parsons A, et al. The effect of Transtheoretical Model based interventions on smoking cessation. Soc Sci Med 2009;68(3):397-403.

59.Handel G, Hannover W, Roske K, et al. Intention to change smoking in pregnan and postpartum women according to number of pregnancies. Eur J Public Health $2009 ; 19(2): 218-21$.

60.Shabani M, Omidi S, Farmanbar R, et al. Effect of preconception counseling on health promoting behaviors of reproductiveage women in Sari city. JNMS. 2016;3(2):1-10.

61.Moshki M, Bahri N, Sadegh Moghadam L. Lifestyle of pregnant women living in Gonabad (Iran). J Res Health 2012;2(2):200-206.

62.Tavakoli N. Examination of the relationship betweenhealth-promoting behaviors and family characteristics inhigh school girl students. J Urmia Nurs Midwifery Facul 2015;13(5):395-403 